\title{
Critical Pedagogy and Eco-pedagogy: Discussing Ethics and Radical Environmentalism at Business School
}

\author{
Helen Kopnina ${ }^{1 *}$
}

\author{
${ }^{1}$ The Hague University of Applied Sciences, International Business Management Studies, THE NETHERLANDS \\ *Corresponding Author: h.kopnina@hhs.nl
}

Citation: Kopnina, H. (2020). Critical Pedagogy and Eco-pedagogy: Discussing Ethics and Radical Environmentalism at Business School. European Journal of Sustainable Development Research, 4(3), em0123. https://doi.org/10.29333/ejosdr/7855

\section{ARTICLE INFO}

Received: 14 Dec. 2019

Revised: 8 Feb. 2020

Accepted: 22 eb. 2020

\begin{abstract}
This article discusses critical pedagogy and ecopedagogy, which stimulate active citizenship through the lessons of environmentalism, exposing students to the critique of the underlying power structures of society. This article discusses business ethics and sustainability undergraduate course, which served as a case study applying critical pedagogy and ecopedogogy. Critical pedagogy, developed by the Brazilian educator Paulo Freire rejects the idea that education is ever politically neutral, arguing that teaching is an inherently political act. Ecopedagogy, taking critical pedagogy further to include current environmental challenges, has inspired this educational intervention described in this article. Asked to watch and reflect on a documentary about radical environmentalism, the students demonstrated a certain shift in their understanding of conventional ethics, enshrined in anthropocentrism. Their reflections showed that they were both surprised and to a degree shocked about not just the actions of the "radicals", but also the role of the state, supported by corporate and political lobbies in suppressing protest and the framing of the term "radicalism". The article concludes in the reflection on what radical environmentalism can teach business students in their role as active citizens.
\end{abstract}

Keywords: active citizenship, critical pedagogy, ecopedagogy, environmental education, radical environmentalism

\section{INTRODUCTION}

Global environmentalism has many manifestations (Castells, 1997), occurring anywhere from the Middle East, Asia (Global Witness 2018), Europe (e.g. Amnesty International, 2018), Africa (e.g. Baletti, Johnson, \& Wolford, 2008) and Australia (e.g. Smee, 2019). Various forms of environmentalism, from indigenous resistance (Wolford 2010) to Extinction Rebellion, active from London (Gayle, 2019) to Brisbane (Smee, 2019), challenge the economy-driven logic of modern industrial society and global capital (Castells 1997). Forest defense activism, a subject discussed in this article, has been a consistent feature of environmental protests. More than 50,000 citizens have protested the destruction of the ancient Hambacher forest in western Germany in 2018 (Queally, 2018). In Poland's last primeval Bialowieza Forest the security guards have forcibly ejected protesters who sought to stop the felling of trees (Barteczko, 2017).

Anti-environmentalism is particularly directed at groups challenging established political hegemonies or economic profit, and dictating Western, Euro- and ethnocentric vision of what human progress is (Kahn, 2010; Taylor, 1995). "On the one hand, the actions of these groups or individuals can be deemed illegal (as in the case of Extinction Rebellion) or as subversive as recognized by the local officials or even community members (as in many cases of activists' deaths in South America, Asia, and Africa). These same actions can be viewed as signs of active citizenship - a necessary step towards the realization of sustainability (O'Riordan, 1999) - on the other hand.

This article will address a question: How is the concept of active citizenship in education related to radical environmentalism? In education, the concept of active citizenship (Poudrier, 2017) is rooted in ideas about active democratic citizenship (Dryzek, 2005), critical pedagogy (Freire, 1972) and ecopedagogy (Kahn, 2010). The latter two fields explicitly engage with the idea of "learning from the activists" to achieve a sustainable future for the entire community (O'Riordan, 1999).

This article will discuss the application of a small part of critical pedagogy and ecopedagogy to the Bachelors-level students at The Hague University of Applied Sciences in The Netherlands. One part of this course intended to expose students to "radical" environmentalism. This article presents a random selection of student reflective essays about the film If a Tree Falls: A Story Of The Earth Liberation Front (https://www.youtube.com/watch?v=UmZkNNJqr1l). The documentary film, released in 2011, was directed by Marshall Curry and Sam Cullman. In 2017, the students were asked to reflect on the film, describing events that have proceeded 
and resulted from actions of this radical group of environmentalists (for background on the group see Brown, 2019b; Kahn, 2010; Lipscher, Coldwell \& Bunch, 2005; Pickering 2002; Scarce, 2006). The underlying reason for conducting this study was to gauge the opinions of business students towards an ultimate anti-business perspective as a starting point of developing critical reflection and active citizenship. This documentary is particularly suited for the critical pedagogy study as it deals with the same group of environmental activists, the ELF, that Kahn (2010) described as having the potential to move students to a realization of the hegemony of regimes that oppose descent. The reflective practice involved in asking students to write an essay on the documentary was targeted to enables a recognition of the hidden assumptions and patterns of behavior that create categories of "radicalism" and other paradigms. This reflective practice, in a miniature, also allows for the exploration of broader questions, such as: How do the student's own upbringing and background relate to the judgments they make? By employing critical pedagogy's methods of personal inquiry, this exercise attempted to nurture greater self-awareness in regard to complex moral questions as to "right" or "wrong."

Below, environmental activism and its suppression and various forms of "radical pedagogies" are briefly summarised, followed by the outline of the methodology used for conducting this study. The student reflection reports are then presented, followed by analysis and reflection.

\section{ACTIVISM AND ANTI-ENVIRONMENTALISM}

In many countries in Eastern Europe, environmental activists were arrested for peaceful protests (Amnesty International, 2018; Lobanov, 2018). In North America, environmentalism ranging from grassroots biodiversity protection groups (Bevington, 2012) to the Occupy movement (Van Gelder, 2011), to the Native (indigenous) protests against mining and manufacturing on their land (Clark, 2002) have been suppressed. With the election of President Donald Trump, the policy of institutionalized antienvironmentalism has expanded to wider institutional "reform", for example substituting climate change scientists by climate skeptics (e.g. Gibbens, 2019; Stehr \& Ruser, 2017).

Even more violent fate awaited environmental activists outside of Western countries (Global Witness, 2017, Guha, 2000; Holmes, 2016; Kopnina, 2005a; Watts, 2018). In Africa, environmental activism has resulted in executions (Nixon, 1996) and suppression of grassroots protests (Baletti et al., 2008). Recent reports of park rangers killed by poachers or illegal loggers have increased (Burke, 2018; Global Conservation, 2018; IUCN, 2017). Environmentalists were killed in Asia, in countries such as the Philippines, one of the deadliest, with over 160 environmental activists killed (Brown, 2019a) and with continued persecution of environmentalists, sometimes with fatalities, in Cambodia (Chheng, 2019; Cohen, 2018; Erickson-Davis, 2018; Global Witness, 2017; You, 2018), China (Jacobs, 2014) and Vietnam (Human Rights Watch, 2016).

\section{RADICAL PEDAGOGIES}

The principles of a critical theory of the Frankfurt school, which emerged in Germany in the 1930s, were represented, among others, by philosophers Theodor Adorno, Herbert Marcuse, and Max Horkheimer. Originating from a Marxist perspective, these principles included a critical social assessment to reveal and challenge power structures. These principles have inspired the work of the Brazilian philosopher, activist, lawyer and educator Paulo Freire (1972). He has developed critical pedagogy is a teaching approach inspired by critical theory, which attempts to help students question and challenge posited "domination" of capitalist, corporate, or political structures.

This critical theory of education was further developed by Richard Kahn, a self-proclaimed "anarcho-vegan activist, who regularly works on behalf of the animal, ecological, and social justice causes", who shifted critical analysis in the direction of ecopedagogy. Both ecopedogogy and critical pedagogy was to challenge the broadly shared assumptions and practices that underline this domination (Kahn, 2010). Having in part evolved from critical pedagogy, ecopedagogy is less ideologically leftist and more environment-centered (Kahn, 2006; Nocella, 2007). Remaining socially critical, ecopedagogy supports the position that learning about environmentalism prepares students to recognize the types of ethics that are seldom taught at school - deep ecology and ecocentrism (Naess, 1973; Sitka-Sage et al, 2017), animal rights and welfare movements (Singer, 1975; Regan, 1984), and inclusive (multispecies) pluralism (Kopnina \& Cherniak, 2016). Assuming that conventional environmental education and particularly education for sustainable development is still influenced by the dominant anthropocentric economic thinking (Bonnett, 2007; Kopnina, 2012, 2015b, 2015c, 2016, 2019), critical pedagogy scholars point out that "industries and the state have strong institutional and monetary biases" against justice for the environment (Nocella, 2007, p. 3).

This translates into the type of education that teaches students to see nature as a resource, not as intrinsically valuable good (Nocella, 2007, p. 3-4). In contrast to conventional education, critical pedagogy outlines "method and process for liberation" and an "approach to fight and unveil the complex and interwoven lies of the global capitalist machine" (Ibid). Critical ecopedagogy "fights for the oppressed, adopts a critical methodology and promotes education as a non-violent form of radical social change" (Nocella, 2007, p. 4). One of the examples of ecopedagogy is advocated by Peter McLaren's 'revolutionary pedagogy' that can heretically challenge market logic and reformist ideology in favor of whole-scale social transformation (McLaren \& Houston, 2005 in Kahn, 2006). McLaren and Houston have even charted a sort of 'eco-socialist pedagogy' that stands in defense of convicted Earth Liberation Front (ELF) activists such as Jeffrey Luers, as it "militates against educational machinations of the mainstream and capitalist status quo" (Kahn, 2006). McLaren and Houston (2005) are informed by "green Marxism" and argue for "dialectics of ecological and environmental justice that highlights the situatedness of environmental conflict and injustice toward nonhuman nature without obscuring its historical production under capitalist value forms" (p. 166). 
Another example of eco-pedagogy is Critical Animal Pedagogy, predicated on the challenge of the examination and eradication of speciesist pedagogies (Grubbs \& Loadanthal, 2014). It is interesting to note that the word "speciesism" is not even recognized in the most common grammar check programs, while terms like racism and sexism, especially in an educational context, carry a very obvious negative connotation. The aim of critical animal pedagogies is, according to Pedersen (2019) is to disentangle animals from the demands we make on them, and thereby also to free ourselves from our harm inflicting behaviors. Grubbs and Loadanthal (2014) note that academics who challenge anthropocentrism are considered to be within a spectrum of activists rather than objective scholars, while, they argue, their challenge addresses the most hegemonic power, which many learners are simply unaware of.

One way of discussing the power hegemonies is recommended by environmental education researcher Richard Kahn (2006; 2010), by introducing the students to some of the "radical" ideas espoused by environmentalists. As Kahn (2006, p. 40) states, the marginalized groups like the Earth Liberation Front "work to educate society as to the gravity of the consequences of their political economy and provide the hope of alternative relationships in the world". Kahn (2006, p. 40) continues that turning "earth warriors into leading pedagogues", who, he admits, "nevertheless stand in need of their education as educators", can significantly contribute to the education of critical, alert, conscientious and active citizens. However, this may well be, not because of the "naivety or insufficiency of the educational projects and political goals mounted by the earth or animal liberation movements, but rather because present versions of academic eco-literacy are themselves seriously, and perhaps gravely, depoliticized" (Ibid).

Critical pedagogy, ecopedagogy, and ecocentric education (Molino-Motos, 2019) challenge the dominant forms of environmental education and education for sustainable development (ESD). They emphasize political, or (un)democratic elements of subordination of environment to industrial and economic interests (Kahn, 2010; Nocella, 2007). Active ecological citizenship begins with an education that reveals the lessons of environmentalism and engages with the underlying power structures of society (Spannring, 2019). One cautious attempt to politicize the issues discussed in business ethics and sustainability courses given o business students is described below.

In many countries in Eastern Europe, environmental activists were arrested for peaceful protests (Amnesty International, 2018; Lobanov, 2018). In North America, environmentalism ranging from grassroots biodiversity protection groups (Bevington, 2012) to the Occupy movement (Van Gelder, 2011), to the Native (indigenous) protests against mining and manufacturing on their land (Clark, 2002) have been suppressed. With the election of President Donald Trump, the policy of institutionalized antienvironmentalism has expanded to wider institutional "reform", for example substituting climate change scientists by climate skeptics (e.g. Gibbens, 2019; Stehr \& Ruser, 2017).

Even more violent fate awaited environmental activists outside of Western countries (Global Witness, 2017; Guha, 2000; Holmes, 2016; Kopnina, 2005a; Watts, 2018). In Africa, environmental activism has resulted in executions (Nixon, 1996) and suppression of grassroots protests (Baletti et al., 2008). Recent reports of park rangers killed by poachers or illegal loggers have increased (Burke, 2018; Global Conservation, 2018; IUCN, 2017). Environmentalists were killed in Asia, in countries such as the Philippines, one of the deadliest, with over 160 environmental activists killed (Brown, 2019a) and with continued persecution of environmentalists, sometimes with fatalities, in Cambodia (Chheng, 2019; Cohen, 2018; Erickson-Davis, 2018; Global Witness, 2017; You, 2018), China (Jacobs, 2014) and Vietnam (Human Rights Watch, 2016).

\section{METHODOLOGY}

The film If A Tree Falls reflections of students described below were intended as an exercise in critical pedagogy in order to elicit student opinions about a group of radical environmental activists, reflecting on ethical and personal lessons. The film was shown to 290 international bachelor students of International Business following the course Business Ethics and Sustainability between January and May 2019 at The Hague University of Applied Sciences (earlier courses involving film analysis are reported in Kopnina 2014, 2015b). This course involved a number of assignments, most of which had to do with business cases and innovation projects, with the film being shown after a lecture on environmental challenges. The purpose of the documentary was to reveal the events leading to the arrests of "eco-terrorists", members of the Earth Liberation Front (ELF), who have engaged in economic sabotage of a number of target industries, such as the horse slaughterhouse and U.S. Forest Industries. The film showed police footage, as well as interviews with the ELF members, the victims of property damage or arson, and the FBI agents.

The students were asked to apply general ethical theories that have been introduced in class. Additionally, the students were provided with the links to ethical theories (http://www.bbc.co.uk/ethics/introduction/intro_1.shtml). The film was not discussed in class prior to students writing their essay not to influence their judgment. After the assignment has been submitted, the lecturer encouraged in-class discussion to share ideas about the film. However, this article only reflects on written assignments.

\section{CASE STUDY: STUDENT REFLECTIONS ON THE FILM IF A TREE FALLS}

Below, four randomly selected reflection assignments (see methodology section above) are presented. Original grammar and style are largely retained, with some minor changes and editing for clarity (as the majority of students were non-native English speakers), and researcher-deleted sections indicated below in squire brackets.

Student 1: I think that this film has two big purposes because it shows you the two sides; as a protester and after they were protesters [...]. The director wanted to transmit a reality that is happening in the world, he wanted to show us how the big 
companies are destroying the environment, killing animals and doing stop that they shouldn't because they only care about the money. They are willing to cut down the forest, [experiment] on animals [...] and do more stuff that damages the world.

But there are people that they won't just see the world burn, people that stood up and defend what they believed and took action all around America to show the government and these big companies that there are people that would do anything to protect the world, they were called ELF, a group of people that would manifest and do things so people would understand or they would stop. Some of the stuff they did was illegal or could have hurt people, but they did it anyway to prove a point.

The other purpose, after they were protesters, I think that was more shocking for me; I saw what they did when they were young because they believed in something and they wanted to be heard and I like that, but when they are older, have families, jobs and everything they realized that what they did, even if it was something they felt it was right at the time, it was wrong the way they showed it. I think that the director wanted to show us these two sides so we would be conscious of the things we do. Because when you believed in something, you are going to defend it, act for it and protect it at all cost, but you have to be wise on how you protest, on how you act and what actions to take about it, because in the future, it might come back to you.

Before I watched the film, I didn't know anything about this movement in the United States, I didn't know about ELF and I didn't know how these big companies polluted the world so much. But, when I was 14 years old, I lived in Canada, a small town where most of it was a forest. The main company there was a paper factory, and I was amazed and I felt so bad every time I went next to that factory. There were millions of trees there, and every day they brought more, on a normal day everyone uses paper, for everything you need it but you never think where does it came from or how did they do it, but after I lived there, every time I see someone cutting down trees it makes me sad about the world.

The main subject of the film for me was the way they manifested what they believed in. They wanted to share with the rest of the United States and to the world what was going on there and that they would do anything to save the planet. The moral argument for me its really big, because on one side I support them, this companies were damaging the world, were doing stuff they shouldn't have done and it was good that someone stood up and said what they thought about it, but then, the way they did it, it was bad, it was vandalism and if you want peace you have to act with peace because if you act with violence they will respond with violence too.

I really liked this film and I think it did a really good job on making people more aware of what's happening with our world, I think it was good for the protesters to act so the world and governments would make conscious about it, but I don't approve the way they did it; burning stuff. Here's where I bump with myself because, on one hand, I agree that these companies deserved it because they are destroying our world just so they are richer, but on the other hand, if I was the owner of that company, and I heard that they burned down the offices of my 30 bans I would be also sad because I spent money on them, I try to make a profit or money out of my business. So, if some protesters burned down my job, it would be so bad. So, for me, the director did a really good job, and young people should watch it so they think about the world before they start a business, they would make it more ethical, ecologic and would think what would damage the world less.

For me, we have to find a balance on our business; one where we don't overuse the natural resources, respect the animal rights, the human rights and we try to protect the world in every decision we make, but at the same time, we are making a profit. Some day we will find it and the world will be a better place.

Student 2: I believe the directors want us to question ourselves how big is the impact of the human race in the environment, especially when there is a massive impact like corporations. Additionally, they make us question if it's reasonable to attack properties to defend an environmental cause, so until what point these actions can or cannot be considered as ethical or moral.

The narration is almost investigative, as there are no journalistic biases, all the opinions, values, motivations and beliefs are exposed with total transparency, so the spectator can choose his position towards this topic.

I had no previous knowledge of what eco-terrorism was. I was only aware of environmental activists who claim for the protection of the natural environment that can be damaged by harmful human activities.

I believe action needs to be taken about the environment, we all should be aware of it, but a huge amount of people doesn't care about it. Big corporations play an important role here because they are the ones who usually look for profits and forget about the primary sources they use, so they end up massively damaging the environment. For example, Steve Swanson, the president of Superior Lumber, mentions they cut down trees but they regrow them according to the law. But this makes me question if they plant as many trees as they cut down, and if they are doing it in a reasonable rhythm that enables the land to recover from the damage caused. This also takes me to another question, are the laws only the minimal required to 'cure' the damage caused or are they well thought and conscious about our environment. I was shocked when I heard Bill Barton, the native forest council, saying that almost $95 \%$ of the standing native forest in the US has been cut 
out. So this affirmation assures me that policies and regulations are not conscious about the environmental damage. How is it possible that only $5 \%$ lasts? Are the ELF group radical because they are trying to preserve that $5 \%$ ? Bill Barton also said that maybe it's not radical to preserve that $5 \%$, radical is cutting down the $95 \%$. Before I finished watching the documental I thought the ELF was too extreme, but this phrase made me understand a little bit more of their reasoning. I believe conscious actions must be also taken from the government and corporations because if they don't get enough involved they are also being radical with the environment. I am not justifying ELF's actions, because I think there is a limit when we protest, we can't go over other people's rights or properties.

I think the directors achieved their goals, they deliver a clear message about the ethical issues, the environment and also the actions taken by ELF to stop big corporations damage the environment. Furthermore, they let the audience choose their position based on facts, investigations and personal views and beliefs from the group members. I would recommend this film because it gives you a broad knowledge about the topic and I liked that they only narrate the facts from a neutral position.

Related to theory, ethics, as a system of moral principles, provides a moral map, a framework that can be used to find the way through difficult issues but it doesn't give an ultimate and right answer. One main point in ethics is that it's concerned with other people's interests, society interests, "ultimate goods", and so on. So when someone 'thinks ethically' they are thinking beyond themselves. According to the documentary, the ELF group care for the environment, also for the people because all the attacks were carefully planned so no people would be damaged. On the other hand, it can be thought that in some way they attacked people in an indirect way because they burned their properties. Modern thinkers often teach that ethics leads to decisions, not conclusions. So ethics must help in providing conversations and value systems that can be applied to this important problem. The difficulty is that people usually follow different ethical codes and moral beliefs. As it's clearly shown in the video, ELF finds justifiable actions because of their personal moral beliefs.

Student 3: The film reveals the origins, ideas, actions, internal and social conflicts of the radical environmental group ELF. From the perspective of police inspection to defense lawyers and ELF members, we explore the current subtle differences between terrorism and revolution in the face of the global environmental crisis. What kind of ways can awaken the awareness of social conservation?

After watching this film, I was a little surprised by the impact it brought me. The American government called the Eco terrorists, which was originally composed of a group of aspiring people who loved the earth and the land forest because they did not want the land to be encroached by the government for commercial use. Therefore, the collective protests blocked the way out into the mountains, and even the struggle that lasted for a year. If they were to say that they were mad, the fact is that many people involved are high-skilled people in various fields. To protect the mountains of the earth, the struggles around the clock, but the inhumane and cruel methods of the police and the government consortium gradually let them lose their faith.

What you can't imagine is that they threw tear gas into the protesters who refused to compromise, used pepper spray and directly squirted eyes (I mean, squirting your eyes and squirting inside) [documentary footage of police arrests]. Many pictures are presented in the movie not remade, but recorded every second of their struggle, recorded when their beliefs are gradually lost. They said, "Why to use this cruel way to deal with these warriors who simply want to express environmental protection convictions!?" [...]. With regard to the vision of the world, they began to plan to use the most extreme way to make these consortia that rely on logging or need to rely on a large number of natural resources to lose their assets, and to operate, to use explosive substances and fight on the streets to destroy the assets of government consortia.

These actions were known as terrorists, but in many countless ELF cases, in addition to the loss of property, there is no half innocent person who is in danger of life. The following short paragraph is ELF on Wikipedia, key points for taking action on the organization: "The goal of ELF is to stop the incredible harm to the environment and help build environmental sustainability. There is a reason why ELF and similar groups exist. That is, many mainstream people because of the effectiveness of the strategy support them. More importantly, ELF receives so much support because, in a world of violent tendencies, ELF has consistently adhered to its creed: never put life at risk of being hurt."

The most important incident in the record is the arson incident planned by Daniel McGowan [...]. The determination to protect this forest, the extreme methods, and many of the mentality and feelings in the arson incident include the mistakes in the plan, his family and friends [...]. If you have seen this documentary, you must not think that he is the so-called arsonist personality in people's mouth in real life. He was the environmental warrior we generally know. It is only a little obsessive-compulsive. In some respects, if you are not good, you will still feel that he was the young people of environmental protection in their thoughts have practiced much persistence in their lives. Therefore, the words "terrorist" should be confusing.

There are many photos of him in the forest and the stream when he was a child. You can deeply feel that he was a "human" who was born with nature. He just wanted to keep everything he saw, the peace and tranquility that he brought to him in the forest [...]. 
It took the FBI many years to unravel many of the savvy criminal suspects, from the hateful and unpleasant arsonists at the beginning, to the FBI police officers saying, "When you get older, you will start to understand the world is not black or white." How do you define them? Good person? Bad guys? The environment has created us... Do you think it has nothing to do with us?

Student 4: The purpose of the documentary was to show the evolution of the ELF in the United States of America, as it showed it precisely with Daniel 's McGowan's story. At the same time, in my opinion, the film gives an important message regarding terrorism, shown along with the movie with the questions asked Daniel about it. Also, the director addressed a message in which peaceful protests without government responses become useless and lead to people reacting in violent ways. This is shown in the movie in the scene around minute 19:40, where there had been a protest against the destruction of some trees. An audience was supposed to take place but the actions against the trees were taking place first. For this, police with pepper spray attacked the protests. Nevertheless, another message transmitted, regarding the moral position of the group, is their attacks supported by the fact that they are protecting the environment and they are not attacking people, but just properties. For me, this is the main moral issue that came to my mind after watching the movie: how can you judge who is the victim or the killer? Companies that are damaging the environment? Or activists who are defending it?

I didn't know that there were groups that took violent actions, reacting to environmental degradation. In Colombia, terrorist groups existed because of differences in political ideologies, but environmental issues were never the justification for a group of those. At the same time, I thought that the USA police and FBI were always focused on attacking international terrorist groups.

On the other hand, I do not agree with the ideals of the ELF, because I think that there are non-violent ways to fight for a specific cause. My favorite message from the film was around minute 3:28, where they stated the idea regarding how the world would 've if everyone burns the things that peeve them of. Showing this my disagreement with the violent reactions from the ELF and my agreement with the comparison of the movie regarding the disaster in which we would live if everyone reacted in a violent way against things they do not like. At the same time, around minute 8:09, they showed a bar in the USA in which all the incomes they received were designated to Wetlands environmental center, showing other ways to improve the environmental issues around the country. [...] People should search for diverse ways to fight for their ideals and I liked the movie for showing them.

The movie was accurate to deliver the director's message. Around minute 30:13 the documentary shows when the ELF burned the facility Cavel West, the images were strong, demonstrating the impossibility for the company to rebuild the property and the extreme actions that the terrorist group was developing. Regarding ethical issues, I learned that it is difficult to judge the actions of a person fighting for their convictions because it is ambiguous to choose the bad and the good side of every situation. Another learning is that the police and FBI are constantly in a moral discussion regarding the use of strong arms, such as the pepper spray, to accomplish their functions. I would recommend the movie to my friends because I think it is an opportunity to let people know deeply why terrorism takes place sometimes to protect convictions and the ethical issues that might be present when judging the victims and the attackers.

Furthermore, regarding the ethical issues, I think it is ambiguous to judge McGowan and the ELF. This, because [...] "For some environmental activists the rights of non-human species have the same moral imperative as the earlier social movements." Their environmental convictions might have the same importance for them, as other convictions, such as fighting for human equality, homosexual rights, between others. Addressing a moral debate between which convictions justify the actions that have been done to protect them. On the other side, the consequentialist ethical theory can also be related to the film. This theory states that an act is morally right depending on the consequences it brings; whether they are good or bad. The acts developed by the ELF are not considered ethically right because of the destruction of the company's properties. Nevertheless, observing those acts from the perspective of the ELF, the consequences were good, because they stopped the environmental damage. The consequentialist ethical theory provides two different judgments regarding the attacks from the ELF. Another ethical theory, ethical formalism, states that people should act guided by the laws that are considered universal. The ELF is going against the preservation of private property as the universal law, and for this, their actions might be ethically incorrect. Finally, the situation ethics, in which the general situation of the act determines if it is ethically correct, suggests that the ELF acts might be correct as they are protecting their environmental convictions. Nevertheless, again, if those situations are seen from the eyes of the companies attacked, it might be ethically incorrect because their properties were damaged.

\section{DISCUSSION OF STUDENT ASSIGNMENTS}

What do these student assignments tell us? Some of the reflections are personal and emphatic, reflecting on the activists' motives (e.g. in regard to McGowan, "You can deeply feel that he was a "human" or to the group "How do you define them? Good person? Bad guys?"), to the complexity of beliefs' and motives' translation into action (e.g. "when you believed in something, you are going to defend it, act for it and protect it at all cost, but you have to be wise on how you protest", "The difficulty is that people usually follow different ethical codes and moral beliefs"). The students can realize the paradoxes embodied in industrial societies, 
but also relativism of the 'right and wrong' ("how can you judge who is the victim or the killer?"; "I learned that it is difficult to judge the actions of a person fighting for their convictions because it is ambiguous to choose the bad and the good side of every situation"; "it is ambiguous to judge McGowan and the ELF"). Motivation was understood to have originated both from the belief that what "corporations" do is wrong, the fact that peaceful protests in the past were not effective, and as a counter-reaction to police violence (e.g. "To protect the mountains of the earth, the struggles around the clock, but the inhumane and cruel methods of the police and the government consortium gradually let them lose their faith" and "peaceful protests without government responses become useless and lead to people reacting in violent ways").

Another manifestation of this relativity is the realization of learning through time, as one student quotes the FBI agent saying "When you get older, you will start to understand the world is not black or white." Another student reflected on what they interpreted as the activists' shift in values as they grew older: "what they did when they were young because they believed in something [...] but when they are older, have families, jobs and everything they realized that what they did, even if it was something they felt it was right at the time..."

One student explicitly reflected on the ethical theories, stating that consequentialism explains ELF's actions ("The acts developed by the ELF are not considered ethically right because of the destruction of the company's properties. Nevertheless, observing those acts from the perspective of the ELF, the consequences were good, because they stopped the environmental damage"). However, students also noted that violent actions also were counter-productive to the cause and different means of protest might have had better outcomes. This leads some to ponder both whether the means justified the ends, and where does the justification lie. The same student that evoked consequentialism, and has contrasted situation ethics and formalistic ethics, pointing out that the former will justify ELF's action and the latter would not.

The students have reflected on their role as citizens or professionals, through the description of their understanding of corporate power, a reflection that has a direct impact on how they, being business students, make judgments. For example, reflecting on the amount of forest used for commercial harvesting, one student reflected on the nature of "radicalism": "Are the ELF group radical because they are trying to preserve that 5\%? [...] maybe it's not radical to preserve that $5 \%$, radical is cutting down the 95\%."

On the other hand, all students disagreed with the methods used by ELF but simultaneously recognized the need to "do something" (e.g. "on one side I support them, this companies were damaging the world [...] but then, the way they did it, it was bad"; "I think it was good for the protesters to act so the world and governments would make conscious about it, but I don't approve the way they did it"; "I do not agree with the ideals of the ELF, because I think that there are non-violent ways to fight for a specific cause"). The students noted that while no people were harmed in ELF attacks, and while their "creed" was "never put life at risk of being hurt", the arson attacks could be seen as going over the limit: "we can't go over other people's right or properties."

In sum, the students demonstrated the ability to identify a certain shift in their understanding of ideas of conventional ethics ("The difficulty is that people usually follow different ethical codes and moral beliefs"), the role of the state in suppressing protest ("differences between terrorism and revolution in the face of the global environmental crisis"), the power of corporate or political actors ("Big corporations play an important role here because they are the ones who usually look for profits and forget about the primary sources they use, so they end up damaging the environment in a massive way").

The case study above is just a very limited example of how environmentalism - presented briefly through exposure to a documentary without discussion in class- has provoked critical thinking in business students. Larger lessons can be learned. As Kahn $(2006,38)$ reflects:

Of course, eco-radicals will also have to learn, grow, and ultimately teach the values and practices that unfold a new sensibility towards life that emerges from the attempt to liberate and reconcile with the Earth proper. In this respect, perhaps, the reimagination of a pro-life politics in which human and non-human beings are understood as both bios and zoë represents for us the great anti-capitalist challenge of the current historical moment. In the face of expanding zoöcide, to think that this could occur without widespread rebellion and, ultimately, revolution seems extremely doubtful.

These lessons of eco-radicalism are different from the dominant forms of environmental education and education for sustainable development, which tends to be politically disengaged and anthropocentric (Bonnett, 2007; Kopnina, 2012; Nocella, 2007; Sitka-Sage et al., 2017), as discussed in the Introduction. By contrast, ecopedagogy, even by brief exposure of students to the documentary film, stimulated student understanding of the underlying power structures of society and reflections on moral relativity, complexity and citizen engagement. Consequent research can delve further into how innovative thinking and creative solutions to environmental problems can draw on the idea of activism and civic engagement.

Consequent research could also address the more global understanding of the scale of environmental crises and social protests that reach beyond American politics and national corporate interests. Some of the issues discussed in critical animal studies education (Pedersen, 2019), or ecocentric education (Molina-Motos, 2019), or indeed in the broader field of ecopedagogy (Kahn, 2006, 2010) engage with students as responsible citizens.

\section{CONCLUSION}

This article has discussed environmental activism and anti-environmentalism in the context of the educational potential of learning from the "radical" ideas espoused by environmentalists that can serve to educate society as to the gravity of the consequences of capitalist or industrial development with prioritization of profit. It was hypothesized that critical pedagogy and 
ecopedagogy, including the types of education that can help address entrenched anthropocentric ideas, can positively contribute to the education of critical and active citizens. The case study above, although limited in scope, demonstrates the students' ability to challenge conventional anthropocentric ethics, and to critically evaluate the dominance of the state in suppressing the protest. The students' positioning as future corporate actors does not prevent them from realizing and criticizing the framing of "radicalism" that in the case of the Earth Liberation Front, partially confronts the very subject of their study - business. As some students have also reflected on their role as citizens, this cautious and limited assignment does demonstrate the potential to develop critically aware young citizens, perhaps more able to act on behalf of the oppressed - be it the radical environmentalists or the environment itself. While the cases discussed above concern but a small randomly selected sample of assignments, these reflections indicate that perhaps a future generation of business students might not accept "business as usual" and come up with the more transformative, perhaps even "radical" solutions to the current ecological challenges.

\section{REFERENCES}

Amnesty International. (2018). Poland: arrests and refusal of entry to environmentalists during the cop24 climate talks. Retrieved on 22 September 2019 from https://www.amnesty.org/en/documents/eur37/9550/2018/en/

Baletti, B., Johnson, T., \& Wolford, W. (2008). "Late mobilization": transnational peasant networks and grassroots organizing in Brazil and South Africa. Journal of Agrarian Change, 8, 290-314. https://doi.org/10.1111/j.1471-0366.2008.00171.x

Barteczko, A. (2017). Poland ejects protesters from ancient forests despite EU calls to halt logging operation. Retrieved on 22 September 2019 from https://www.reuters.com/article/us-poland-eu-logging-idUSKBN1A61XY

Bevington, D. (2012). The rebirth of environmentalism: grassroots activism from the spotted owl to the polar bear. Washington, D. C.: Island Press.

Bonnett, M. (2007). Environmental education and the issue of nature. Journal of Curriculum Studies, 39(6), 707-721. https://doi.org/10.1080/00220270701447149

Brown, A. (2019a). More than 160 environmental defenders were killed in 2018, and many others labeled terrorists and criminals. Retrieved on 22 September 2019 from https://theintercept.com/2019/07/30/criminalization-environmental-activists-globalwitness-report/

Brown, A. (2019b). The green scare. Retrieved on 22 September 2019 from https://theintercept.com/2019/03/23/ecoterrorism-fbianimal-rights/

Burke, J. (2018). Six Virunga park rangers killed in DRC wildlife sanctuary. Retrieved on 22 September 2019 from https://www.theguardian.com/weather/2018/apr/09/six-virunga-park-rangers-killed-in-drc-wildlife-sanctuary

Castells, M. (1997). The Power of Identity. Oxford: Blackwell.

Chheng, N. (2019). Spanish nature activist court hearing begins. Retrieved on 22 September 2019 from https://www.phnompenhpost.com/national/spanish-nature-activist-court-hearing-begins

Clark, B. (2002). The Indigenous Environmental Movement in the United States: Transcending Borders in Struggles Against Mining, Manufacturing, and the Capitalist State. Organization \& Environment, 15(4), 410-442. https://doi.org/10.1177/1086026602238170

Cohen, J. (2018). Five years since the murder of our friend Chut Wutty. Retrieved on 22 September 2019 from https://www.globalwitness.org/en/blog/five-years-murder-our-friend-chut-wutty/

Collinson, H. (1996). Green Guerrillas: environmental conflicts and initiatives in Latin America and the Caribbean. Latin America Bureau, Ltd.

Dryzek, J. S. (2005). The Politics of the Earth: Environmental Discourses. Second Edition. Oxford: Oxford University Press.

Erickson-Davis, M. (2018). More murders: Conservationists allegedly killed by soldiers in Cambodia. Retrieved on 22 September 2019 from https://news.mongabay.com/2018/01/more-murders-conservationists-allegedly-killed-by-soldiers-in-cambodia/

Freire, P. (1972). Pedagogy of the Oppressed. New York: Herder \& Herder.

Gayle, D. (2019). Shami Chakrabarti warns police over Extinction Rebellion prosecutions. Retrieved on 22 September 2019 from https://www.theguardian.com/uk-news/2019/may/25/shami-chakrabarti-warns-police-over-extinction-rebellionprosecutions

Gibbens, S. (2019). 15 ways the Trump administration has changed environmental policies. Retrieved on 22 September 2019 from https://www.nationalgeographic.com/environment/2019/02/15-ways-trump-administration-impacted-environment/

Global Conservation. (2018). Over one thousand park rangers die in 10 years. Retrieved on 22 September 2019 from http://globalconservation.org/news/over-one-thousand-park-rangers-die-10-years-protecting-our-parks/

Global Witness. (2017). Defenders of the earth. Retrieved on 22 September 2019 from https://www.globalwitness.org/en/campaigns/environmental-activists/defenders-earth/

Grubbs, J. \& Loadenthal, M. (2014). From the classroom to the slaughterhouse: Animal liberation by any means necessary. Counterpoints, 448, 179-201.

Guha, R. (2000). Environmentalism: Global History. New York: Longman. 
Holmes, G. (2016). Environmental activist murders set a record as 2015 became the deadliest year. Retrieved on 22 September 2019 from https://www.theguardian.com/environment/2016/jun/20/environmental-activist-murders-global-witness-report

Human Rights Watch. (2016). Vietnam: Crackdown on Peaceful Environmental Protesters. Retrieved on 22 September 2019 from https://www.hrw.org/news/2016/05/18/vietnam-crackdown-peaceful-environmental-protesters

Jacobs, A. (2014). Despite Persecution, Guardian of Lake Tai Spotlights China's Polluters. Retrieved on 22 September 2019 from https://www.nytimes.com/2014/11/24/world/despite-persecution-guardian-of-lake-tai-spotlights-chinas-polluters.html

Kahn, R. (2006). The educative potential of ecological militancy in an age of big oil: Towards a Marcusean ecopedagogy. Policy futures in education, 4(1), 31-44. https://doi.org/10.2304/pfie.2006.4.1.31

Kahn, R. (2010). Critical Pedagogy, Ecoliteracy, and Planetary Crisis: The Ecopedagogy Movement. New York: Peter Lang.

Kopnina, H. (2012). Education for Sustainable Development (ESD): The turn away from 'environment' in environmental education? Environmental Education Research, 18(5), 699-717. https://doi.org/10.1080/13504622.2012.658028

Kopnina, H. (2014). If a Tree Falls: Business students' reflections on environmentalism. International Journal of Environment and Sustainable Development, 8(3), 311-329. https://doi.org/10.1504/IJISD.2014.066621

Kopnina, H. (2015a). Revisiting the Lorax complex: Deep ecology and biophilia in cross-cultural perspective. Environmental Sociology, 43(4), 315-324. https://doi.org/10.1080/23251042.2015.1048765

Kopnina, H. (2015b). If a Tree Falls and Everybody Hears the Sound: Teaching deep ecology to business students. Journal of Education for Sustainable Development, 9(1), 101-116. https://doi.org/10.1177/0973408215569119

Kopnina, H. (2015c). Metaphors of Nature and Development: Reflection on the critical course of sustainable business. Environmental Education Research, 22(4), 571-589. https://doi.org/10.1080/13504622.2015.1007338

Kopnina, H. (2016). Of Big Hegemonies and Little Tigers: Ecocentrism and Environmental Justice. Special Issue "On the politics of policy-making for education for sustainable development". The Journal of Environmental Education, 47(2), $132-150$. https://doi.org/10.1080/00958964.2015.1048502

Kopnina, H. (2019). Green-washing or best case practice? Using a circular economy and Cradle to Cradle case studies in educational practice. Journal of Cleaner Production, 219, 613-623. https://doi.org/10.1016/j.jclepro.2019.02.005

Kopnina, H., \& Blewitt, J. (2014). Sustainable Business: Key issues. Routledge, New York. https://doi.org/10.4324/9781315816586

Kopnina, H., \& Cherniak, B. (2016). Neoliberalism and Justice in Education for Sustainable Development: A call for inclusive pluralism. Environmental Education Research, 22(6), 827-841. https://doi.org/10.1080/13504622.2016.1149550

Lewis, T. L. (2009). Environmental Movements in the Global South. In K. Gould \& T. Lewis (eds.) Twenty Lessons in Environmental Sociology (p. 244-254). New York: Oxford University Press.

Lipscher, S., Coldwell, A., \& Bunch, J. (2005). Vail arson suspect dead. Retrieved on 22 September 2019 from https://www.denverpost.com/2005/12/22/vail-arson-suspect-dead/

Lobanov, V. (2018). Leading Environmentalists Violently Attacked in Russia. Retrieved on 22 September 2019 from https://www.hrw.org/news/2018/01/12/leading-environmentalists-violently-attacked-russia

Mallory, C. (2006). Ecofeminism and Forest Defense in Cascadia: Gender, Theory and Radical Activism. Capitalism Nature Socialism, 17(1), 32-49. https://doi.org/10.1080/10455750500505408

McLaren, P., \& Houston. D. (2005). Revolutionary Ecologies: ecosocialism and critical pedagogy. In P. McLaren, Capitalists \& Conquerors: a critical pedagogy against empire (pp. 166-188). Lanham: Rowman \& Littlefield. https://doi.org/10.1207/s15326993es3601_4

Mercier, J. (1997). Downstream and upstream ecologists. The people, organizations, and ideas behind the movement. Westport (Connecticut): Praeger.

Molina-Motos, D. (2019). Ecophilosophical Principles for an Ecocentric Environmental Education. Education Sciences, 9(1), 37. https://doi.org/10.3390/educsci9010037

Naess, A. (1973). The shallow and the deep: long-range ecology movement. A summary. Inquiry 16, 95-99. https://doi.org/10.1080/00201747308601682

Nixon, R. (1996). Pipe dreams: Ken Saro-Wiwa, environmental justice, and micro-minority rights. Black Renaissance, 1(1), 39.

Nocella, A. (2007). Unmasking the animal liberation front using critical pedagogy: Seeing the ALF for who they are. Journal for Critical Animal Studies, 1, 1-10.

O'Riordan, T. (1999). From environmentalism to sustainability. Scottish Geographical Journal, 115(2), $151-165$. https://doi.org/10.1080/14702549908553824

Pedersen, H. (2019). The Contested Space of Animals in Education: A Response to the "Animal Turn" in Education for Sustainable Development. Education Sciences, 9(3), 211. https://doi.org/10.3390/educsci9030211

Pickering, L. J. (2002). The Earth Liberation Front: 1997-2002. South Wales, NY: Arissa Publications.

Poudrier, C. (2017). Environmental education and active citizenship. Journal of Applied Technical and Educational Sciences, 7(4), 31-36. 
Queally, J. (2018). Fifty-Thousand Come Together in Germany to Defend Ancient Forest and Fight Coal. Retrieved on 22 September 2019 from https://www.commondreams.org/news/2018/10/06/fifty-thousand-come-together-germany-defend-ancientforest-and-fight-coal

Regan, T. (1984). The Case for Animal Rights. Routledge: London.

Scarce, R. (2006). Eco-Warriors: Understanding the Radical Environmental Movement. Walnut Creek, CA: Left Coast Press.

Singer, P. (1975). Animal Liberation: A New Ethics for Our Treatment of Animals. New York: New York Review/Random House.

Sitka-Sage, M. D., Kopnina, H., Blenkinsop, S., \& Piersol, L. (2017). Rewilding Education in Troubling Times; or, Getting Back to the Wrong Post-Nature. Visions for Sustainability, 8, 1-19.

Smee, B. (2019). Queensland police arrest 56 climate change protesters in Brisbane. Retrieved on 22 September 2019 from https://www.theguardian.com/environment/2019/aug/06/queensland-police-arrest-56-climate-change-protesters-inbrisbane

Spannring, R. (2019). Ecological Citizenship Education and the Consumption of Animal Subjectivity. Education Sciences, 9(1), 41. https://doi.org/10.3390/educsci9010041

Stehr, N., \& Ruser, A. (2017). Climate change, governance, and knowledge. In T. B. Brønnum Scavenius \& S. Rayner (Eds.) Institutional Capacity for Climate Change Response (p. 15-30) New York: Routledge. https://doi.org/10.9774/GLEAF.9781315651354_3

Taylor, B.R. (1995). Ecological Resistance Movements: The global emergence of radical and popular environmentalism. SUNY Press.

Van Gelder, S. (Ed). (2011). This Changes Everything: Occupy Wall Street and the 99\% Movement. San Francisco: Berret-Koehler Publishers.

Watts, J. (2018). Almost four environmental defenders a week killed in 2017. Retrieved on 22 September 2019 from https://www.theguardian.com/environment/2018/feb/02/almost-four-environmental-defenders-a-week-killed-in-2017

Wolford, W. (2010). This Land is Ours Now: Social Mobilization and the Meanings of Land in Brazil. Durham and London: Duke University Press. https://doi.org/10.1215/9780822391074

You, S. (2018). After my release, I want to protect the environment even more. Retrieved on 22 September 2019 from https://www.voacambodia.com/a/after-my-release-i-want-to-protect-the-environment-even-more-says-hunvannak/4635068.html

Youkee, M. (2018). Indigenous Chileans defend their land against loggers with radical tactics. Retrieved on 22 September 2019 from https://www.theguardian.com/world/2018/jun/14/chile-mapuche-indigenous-arson-radical-environmental-protest 